\title{
EFEK HEPATOPROTEKTOR FRAKSI TIDAK TERSABUNKAN DARI DALMS TERHADAP KONDISI STRES OKSIDATIF PADA TIKUS WISTAR
}

\author{
YuyunWahyuni \\ Program Studi Agroteknologi Fakultas Pertanian Universitas Nusa Nipa Maumere \\ Jl. Kesehatan No. 03 Maumere \\ Email : uyung210683@yahoo.co.id
}

\begin{abstract}
Effect Of Hepatoprotector Fraction Understanding From Dalms On Oxidative Stress Conditions In Wistar Rats. Palm oil fatty acid distillate (POFAD) is a byproduct of the process of refining palm oil, which still contains compounds. As a result of the increasing production of palm oil in Indonesia and POFAD, making POFAD has the potential as a source of tocotrienols, which can act as natural antioxidants and protect the liver against oxidative stress. The purpose of this study was to study the effects of hepatoprotection of the non-atomized fraction of POFAD in vivo and to find out the best dose of non-soapy fraction of POFAD on MDA levels, SOD of rat liver, and histopathological features in oxidative stress conditions due to waste cooking oil intake. The study design used was a Completely Randomized Design (CRD) which was composed of 6 treatment groups consisting of negative (normal), positive (indiscriminate) control groups, non-dose fraction I (100 mg/kg BW) fractions, non-soapy fractions dose II (200 mg/kg body weight), nonatomic dose III (500 mg/kg body weight), the non-dose fraction (1000 mg/kg body weight) and each treatment were repeated four times. Observational data obtained were processed statistically with the ANOVA test and continued with the Smallest Significant Difference Test (BNT) processed with SPSS for Windows 16 series. The results of this study indicate that the non-soapy fraction of palm oil fatty acid distillates has the ability to protect the liver from organ damage to dose III, namely the administration of non-soapy fractions at a dose of $500 \mathrm{mg} / \mathrm{kg}$ body weight.
\end{abstract}

Key Words: Bioactive Compounds, Non-Draped Faction

\section{PENDAHULUAN}

Ketahanan pangan adalah isu global Pertanian (Food and Agriculture saat ini, di mana Organisasi Pangan dan Organisation atau "FAO") melaporkan 
bahwa lebih dari 815 juta orang mengalami kekurangan gizi kronis. Minyak kelapa sawit, sebagai sebuah komoditas yang mendukung Pembangunan Berkelanjutan memainkan peran penting dalam menyediakan sumber pangan dunia baik secara langsung maupun tak langsung, dan akan terus berperan penting dalam menghadapi tantangan ini. Limbah dari minyak sawit inipun mempunyai keunggulan karena mengandung vitamin $\mathrm{E}$ yang sangat tinggi.

Dewasa ini permasalahan kesehatan dan munculnya berbagai macam penyakit mendorong banyaknya upaya manusia untuk mengeksplorasi penyebab munculnya penyakit dan menemukan solusinya. Pada dasarnya suatu penyakit muncul diawali dengan kerusakan sel. Salah satunya disebabkan oleh terpaparoksidasi yang tinggi (stres oksidatif).

Stres oksidatif merupakan suatu
keadaan ketidakseimbangan antara
produksi senyawa turunan oksigen dan
sistem antioksidan tubuh (Robbins et al.,
1999) Menurut Riegger (2008), stres
oksidatif akibat radikal bebas
menyebabkan peroksidasi lemak,

rusaknya molekul lemak (fosfolipid) membran sel, rusaknya DNA dan oksidasi protein. Stres oksidatif akibat radikal bebas dapat terjadi salah satunya karena induksi minyak jelantah.Pada penelitian Maulana (2011), induksi minyak jelantah secara in vivo pada tikus wistar dengan bilangan peroksida $118 \mathrm{mek} / \mathrm{kg}$ ternyata menimbulkan stres oksidatif. Pengamatan sel hepar tikus secara histopatologi menunjukkan bahwa kelompok kontrol positif yaitu kelompok dalam kondisi stres oksidatif (pakan standar + minyak jelantah) mengalami stres oksidatif yang berdampak pada banyaknya sel hepar yang mati atau mengalami nekrosis.

Vitamin $E$ adalah salah satu antioksidan alami yang terdapat dalam bahan pangan terutama berasal dari minyak sawit, minyak biji bunga matahari, minyak jagung, minyak kedelai dan minyak zaitun (Youngson, 2005). Vitamin $\mathrm{E}$ ini berpotensi sebagai penangkal stres oksidatif. Bahan lainyang dapat menjadi sumber vitamin $\mathrm{E}$ alami adalah distilat asam lemak minyak sawit (DALMS).

DALMS merupakan hasil samping proses pengolahan minyak sawit pada proses deodorisasi. Hasil samping proses 
tersebut masih mengandung vitamin $\mathrm{E}$ alami yang terdiri dari tokoferol dan tokotrienol dengan kadar $1 \%$ (Lewis, 2001). Jumlah DALMS yang dihasilkan pada proses pengolahan sawit di Indonesia tahun 2007 mencapai 4,14 juta ton (Ekonomi dan Bisnis, 2007 dalam Ahmadi, 2010). Jumlah ini akan terus bertambah karena produksi minyak kelapa sawit di Indonesia terus meningkat dan pada tahun 2011 saja mencapai 25,2 juta ton (GAPKI, 2011). Hal tersebut menunjukkan bahwa keberadaan DALMS yang melimpah berpotensi sebagai sumber vitamin E alami.

Selama ini penelitian tentang manfaat vitamin E selalu identik dengan tokoferol, sehingga penelitian tentang tokotrienol lebih sedikit. Padahal menurut Perricon (2008), tokotrienol dapat bekerja 40-60 kali lebih efektif dalam mencegah kerusakan akibat radikal bebas daripada $\alpha$ tokoferol. Sen et al. (2010) menyatakan pula bahwa fraksi kaya tokotrienol pada minyak sawit mengandung tokotrienol hingga $70 \%$ bagian. Pemurnian vitamin E dalam penelitian Rahmawati (2010) menghasilkan tokotrienol dalam fraksi kaya tokotrienol sebesar 21,8\%, lebih tinggi dibanding total tokoferolnya
(14,56\%). Pada penelitian Budin et al. (2009) fraksi kaya tokotrienol terbukti dapat menurunkan stres oksidatif pada tikus terinduksi streptozotocin. Berdasarkan potensi DALMS dan tokotrienol sebagai antioksidan, maka perlu dikaji bagaimana kemampuan fraksi kaya tokotrienol dari DALMS dalam melindungi organ hepar tikus pada kondisi stres oksidatif.

Selama ini belum ada penelitian yang mengkaji bagaimana kemampuan fraksi tidak tersabunkan yang terdapat dalam DALMS yang mengandung senyawa bioaktif multikomponen dan komponen yang paling tinggi adalah vitamin E sebagai antioksidan dalam melindungi organ hepar tikus pada kondisi stres oksidatif dilihat dari kajian kadar Malondialdehid(MDA), Superoksida dismutase (SOD) dan histopatologi organ hepar.

Tujuan dari penelitian ini adalah: Mempelajari efek hepatoprotektor fraksi tidak tersabunkan dari DALMS secara in vivo dan untuk mengetahui dosis terbaikfraksi tidak tersabunkan dari DALMS terhadap kadar MDA, SOD dari organ hepar tikus, serta gambaran 
histopatologi pada kondisi stres oksidatif akibat asupan minyak jelantah

\section{BAHAN DAN METODE}

\section{Waktu dan tempat}

Penelitian ini dilaksanakan pada tahun 2018 bertempat Laboratorium Kimia dan Biokimia Pangan Hasil Pertanian, Jurusan Teknologi Hasil Pertanian, Fakultas Teknologi Pertanian, Universitas Brawijaya. Sedangkan tempat pembuatan fraksi tidak tersabunkan dan analisa kimia, Laboratorium Nutrisi Pangan, Jurusan Teknologi Hasil Pertanian, Fakultas Teknologi Pertanian, Universitas Brawijaya, tempat pemeliharaan tikus dan aplikasi perlakuan in vivo, Laboratorium Farmako, Fakultas Kedokteran, Universitas Brawijaya, tempat pengujian kadar MDA dan SOD, Laboraturium Anatomi dan Patologi, Fakultas Kedokteran, Universitas Brawijaya, tempat pengamatan gambaran histopatologi sel hepar tikus dan Laboratorium Sentra Kimia Jurusan Kimia Universitas Negeri Malang. Penelitian terdiri dari pembuatan fraksi tidak tersabunkan dan pengujian kemampuan hepatoprotektor fraksi tidak tersabunkan secara in vivo. Rancangan penelitian yang digunakan adalah Rancangan Acak Lengkap (RAL).

\section{A. Pembuatan Fraksi Tidak}

\section{Tersabunkan}

Pada tahap ini dilakukan pada DALMS untuk memisahkan asam lemak bebas dari fraksi tidak tersabunkan. Proses pembuatan Fraksi Tidak Tersabunkan dilakukan dengan proses saponifikasi mengacu pada penelitian Muchlisiyah (2012) dimana Fraksi Tidak Tersabunkan ini akan dianalisa kandungan bioaktifnya. Langkah-langkah saponifikasi adalah sebagai berikut:

- DALMS sebanyak 100 g dimasukkan ke dalam erlenmeyer 2 L bertutup karet.

- Etanol sebanyak $883 \mathrm{ml}, 5 \mathrm{~g}$ asam askorbat dan $60 \mathrm{ml} \mathrm{KOH} \mathrm{50 \%} \mathrm{(b/v)}$ ditambahkan pada erlenmeyer $2 \mathrm{~L}$.

- Pencampuran dilakukan menggunakan magnetic stirer.

- Erlenmeyer dipanaskan dalam waterbath suhu $70^{\circ} \mathrm{C}$ selama 32 menit.

- Setelah pemanasan selesai, campuran reaksi dipindahkan ke dalam corong pemisah dan didinginkan pada suhu kamar. 
Wahyuni: Efek hepatoprotektor fraksi tidak tersabunkan dari dalms

- Sebanyak 1500 ml heksana dan 2000 ml akuades ditambahkan, kemudian dilakukan pengocokan lambat dan didiamkan selama \pm 1 jam.

- Lapisan air dibawah mengandung fraksi tersabunkan dan lapisan heksana di bagian atas mengandung fraksi tidak tersabunkan.

- Heksana dipisahkan dari fraksi tidak tersabunkan dengan menggunakan evaporasi vakum dan dihasilkan fraksi tidak tersabunkan bebas pelarut.

\section{B. RancanganPercobaan}

Tikus Rattus norvegicus jantan setelah diadaptasikan dibagi menjadi 6 kelompok masing-masing terdiri dari 4 ekor tikus. Induksi peroksidasilipid dilakukan dengan memberikan asupan minyak jelantah dengan tingkat oksidasi yang diukur dengan bilangan peroksida $116 \mathrm{mek} / \mathrm{kg}$. Minyak jelantah diberikan dengan dosis $2 \mathrm{ml} /$ hari setiap hari dengan disonde selama masa adaptasi dan percobaan. Masa adaptasi dilakukan selama 7 hari. Tikus di beri fraksi tidak tersabukan dengan dosis berfariasi selama 28 hari percobaan dengan cara disonde. Selama masa adaptasi dan percobaan, tikus diberi pakan jenis pulp susu. Adapun jenis perlakuan yang dilakukan adalah sebagai berikut:

K1 : kelompok tikus tanpa diberi minyak jelantah

K2 : kelompok tikus diberi minyak jelantah (FTT dosis $0 \mathrm{mg} / \mathrm{kg}$ bb)

K3 : kelompok tikus diberi minyak jelantah + FTT dosis100 mg/kg bb

K4 : kelompok tikus diberi minyak jelantah + FTT dosis200 mg/kg bb K5 : kelompok tikus diberi minyak jelantah + FTT dosis $500 \mathrm{mg} / \mathrm{kg}$ bb

K6 :kelompok tikus diberi minyak jelantah + FTT dosis 1000 mg/kg $\mathrm{bb}$

Pelaksanaan penelitian dilakukan dalam 2 tahap yaitu:

\section{Saponifikasi}

Saponifikasi dilakukan pada DALMS untuk memisahkan asam lemak bebas dengan fraksi tidak tersabunkan. Tahapan proses saponifikasi adalah sebagai berikut: 100g DALMS, $800 \mathrm{ml}$ etanol, $4 \mathrm{~g}$ asam askorbat, $60 \mathrm{ml} \mathrm{KOH}$ $40 \%$ (b/v) dipanaskan dalam waterbath suhu $69,1^{0} \mathrm{C}$ selama 38 menit. Setelah pemanasan selesai larutan dimasukkan kedalam corong pemisah, kemudian 1500 $\mathrm{ml}$ heksana dan $2000 \mathrm{ml}$ akuades ditambahkan ke dalam corong pemisah 
dan dikocok. Larutan didiamkan sampai terbentuk dua lapisan yaitu lapisan air dibawah mengandung fraksi tersabunkan dan lapisan heksana di bagian atas mengandung fraksi tidak tersabunkan. Fraksi tersabunkan dibuang, sedangkan fraksi tidak tersabunkan diambil.

\section{Tahap In Vivo}

Tahap in vivo dilakukan setelah proses pembuatan fraksi tidak tersabunkan selesai. Tahap ini meliputi aklimatisasi (masa adaptasi) selama 1 minggu dan 4 minggu (28 hari) penelitian utama dengan diet normal, induksi minyak jelantah dan pemberian fraksi tidak tersabunkan, serta pengujian bio-assay terhadap organ hepar tikus untuk menentukan kadar MDA, SOD, dan pengamatan histopatologi sel hepar.

Tahap in vivo yang digunakan adalah True Experimental. Dengan penelitian True Experimental ini, peneliti bertujuan mengetahui suatu gejala atau pengaruh yang timbul sebagai akibat dari adanya perlakuan tertentu. Ciri khusus dari penelitian eksperimen adalah adanya percobaan atau trial. Percobaan itu berupa perlakuan atau intervensi terhadap suatu variabel. Dari perlakuan tersebut diharapkan terjadi perubahan terhadap variabel yang lain (Notoatmodjo, 2005). Sampel penelitian dibagi menjadi 3 kelompok, yaitu:

1. Kelompok control positif (kondisi stresoksidatif)

Pemberian diet normal + minyak jelantah $2 \mathrm{ml}$ secara oral selama 4 minggu

2. Kelompok control negatif Pemberian diet normal saja selama 4 minggu

3. Empat (4) Kelompok perlakuan (kondisi stresoksidatif + fraksi tidak tersabunkan).

Pemberian diet normal + minyak jelantah $2 \mathrm{ml}+$ pemberian fraksi tidak tersabunkan dosis 1,2,3, dan 4 (masing-masing dilarutkan dengan minyak goreng sebanyak1 ml) secara oral selama 4 minggu. Jumlah sampel tikus tiap kelompok yang digunakan dalam penelitian ini adalah 4 ekor sehingga jumlah total tikus adalah 24 ekor. Adapun alur tahap in vivo dijelaskan pada Gambar 1 dan 2. Pemberian pakan disertai dengan air minum yang diberikan secara ad libitum satu kali setiap hari per ekor tikus. Kebutuhan makanan tikus dewasa per ekor setiap hari adalah 30 gram (Tsalissavrina, 2006). 


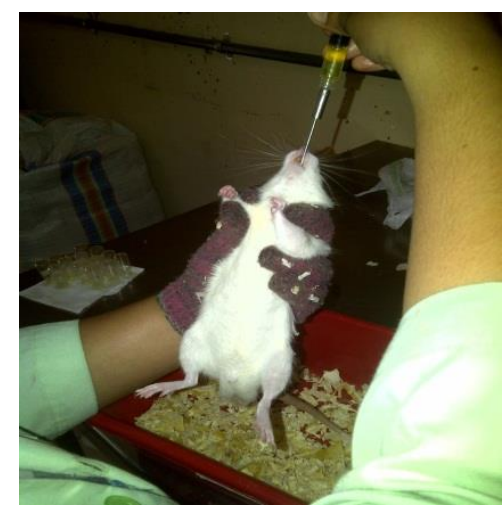

Gambar 1. Pemberian Minyak Jelantah

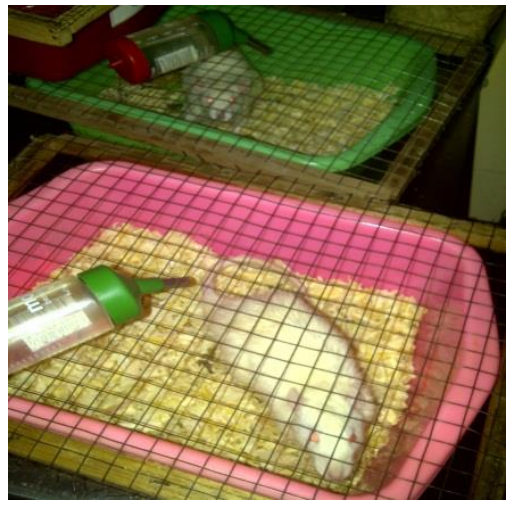

Gambar 2. Pemberian Pakan

Penambahan minyak jelantah sebanyak $2 \mathrm{ml}$ (fraksi tidak tersabunkan) yang telah dilarutkan dalam minyak goreng sebanyak $1 \mathrm{ml}$ diberikan secara oral (force feeding) menggunakan sonde atau gastrointestinal tube (tidak melebihi kapasitas maksimal lambung tikus yaitu 5 ml). Minyak jelantah yang dipakai dalam penelitian ini adalah minyak jelantah yang diperoleh dari pedagang lalapan ayam di kota Malang dan diinduksikan kepada tikus sebagai sumber radikal bebas yang bertujuan untuk menciptakan kondisi stres oksidatif.

Sampel minyak jelantah yang diinduksikan merupakan minyak jelantah yang berbeda namun merupakan minyak bekas untuk menggoreng jenis makanan yang sama yaitu ayam goreng. Pemberian minyak jelantah secara oral dilakukan pada pagi hari (pukul 09.00) sedangkan pemberian fraksi tidak tersabunkan 
dilakukan pada sore hari (pukul 16.00). Hal ini dilakukan untuk memaksimalkan metabolisme hewan uji terhadap minyak jelantah dan fraksi tidak tersabunkan.

Besarnya dosis fraksi tidak tersabunkan yang akan diberikan pada hewan coba, dianalogikan dengan dosis terhadap manusia. Pemberian fraksi tidak tersabunkan pada tikus didasarkan RDA (Recommended Daily Allowance) untuk manusia Eropa sebesar $500 \mathrm{mg}$ (EFSA,2008) dan 500-2500 mg/orang/hari (USANA, 1999). Dengan asumsi berat badan manusia $50 \mathrm{~kg}$, maka kebutuhan vitamin E adalah 10-50 mg/kg BB. Dari hasil penelitian sebelumnya (Puspitasari, 2012), kadar vitamin E dalam fraksi tidak tersabunkan adalah 1,96\%, maka konversinya adalah Kebutuhan minimal vitamin $\mathrm{E}$ manusia $=10 \mathrm{mg} / \mathrm{kg}$ BB

Fraksi tidak tersabunkan yang dibutuhkan agar dosis minimal tercukupi:

$$
\mathrm{F}=\frac{100 \%}{1,96 \%} \times 10 \frac{\mathrm{mg}}{\mathrm{kg}} B B=510,20 \frac{\mathrm{mg}}{\mathrm{kg}} B B
$$

Berdasarkan perhitungan tersebut, aplikasi pada tikus dirancang dengan memberikan dosis rendah, sedang, dan tinggi untuk mengetahui pengaruh variasi dosis yaitu sebesar 100, 200, 500 dan $1000 \mathrm{mg} / \mathrm{kg} \mathrm{BB}$, di mana pemberian dosis pada tikus dengan berat rata-rata 200 g/ekor (0,2 kali dosis manusia) menjadi 20, 40, 100 dan 200 mg/BBT (berat badan tikus). Jadi, dosis perlakuan tersebut dideskripsikan sebagai berikut:

Dosis $\mathrm{I}=100 \mathrm{mg} / \mathrm{kg}$ BB (20 mg fraksi tidak tersabunkan/tikus/hari)

Dosis II = $200 \mathrm{mg} / \mathrm{kg} \mathrm{BB} \mathrm{(40} \mathrm{mg} \mathrm{fraksi}$ tidak tersabunkan /tikus/hari)

Dosis III = 500 mg/kg BB (100 mg fraksi tidak tersabunkan /tikus/hari)

Dosis IV = $1000 \mathrm{mg} / \mathrm{kg}$ BB (200 mg fraksi tidak tersabunkan /tikus/hari)

\section{ANALISIS DATA}

Data pengamatan yang diperoleh diolah secara statistic dengan uji ANOVA dan dilanjutkan dengan Uji Beda Nyata Terkecil (BNT) yang diolah dengan SPSS for Windows seri 16. Data hasil penelitian berupa preparat selhepar diamati histopatologi secara mikroskopis dan dianalisa menggunakan metode analisa skala kerusakan hati secara kualitatif dengan metode Sun et al. (1999) dan didukung dengan analisa kuantitatif yang berasal dari perhitungan sel hati yang terdegenerasi. 
HASIL DAN PEMBAHASAN

Distilat Asam Lemak Minyak Sawit

Bahan baku yang digunakan dalam

penelitian ini adalah distilat asam lemak minyak sawit (DALMS) yang merupakan hasil samping pemurnian minyak kelapa sawit pada tahap deodorisasi.

Tabel 1. Data Hasil Analisa Distilat Asam Lemak Minyak Sawit dan Fraksi Tidak Tersabunkan

\begin{tabular}{lll}
\hline Karakteristik & DALMS & FTT \\
\hline Kadar asam lemak bebas $(\%)$ & 87,83 & 1,37 \\
Bilangan peroksida (mek/kg) & 1,53 & 12,18 \\
Bilangan anisidin & 6,92 & 10,35 \\
Bilangan total oksidasi & 9,98 & 34,71 \\
\hline
\end{tabular}

Sumber : Muchlisyiyah (2013)

Superoksida Dismutase (SOD) dalam Organ Hepar

Pengukuran kadar SOD dari organ hepar tikus yang dilakukan pada minggu akhir perlakuan. Rerata kadar SOD dari organ hepar tikus pada kelompok kontrol negatif adalah 23,78 unit/ml, kelompok kontrol positif adalah 11,35 unit/ml, kelompok dosis I 16,12 unit/ml, kelompok dosis II 18,23 ml/unit, kelompok dosis III 22,44 unit/ml, dan kelompok dosis
IV19,43 unit/ml. Kadar SOD organ hepar yang terkecil adalah pada kelompok kontrol positif dan yang terbesar pada kelompok kontrol negatif.

Hasil uji statistik ragam (ANOVA) menunjukkan hasil bahwa faktor jenis perlakuan memberikan pengaruh yang nyata $(\alpha=0,05)$ terhadap kadar SOD organ hepar tikus. Berdasarkan hasil tersebut perlu dilakukan uji Beda Nyata Terkecil (BNT). 
AGRICA, Vol. 13, No. 1 (2020)

Tabel 2. Rerata Kadar SOD Organ Hepar pada Berbagai KelompokPerlakuan

\begin{tabular}{lc}
\hline Jenis Perlakuan & Kadar SOD (unit/ml) \\
\hline Kontrol negatif (normal) & $23,78 \mathrm{e}$ \\
Kontrol positif (stres oksidatif) & $11,35 \mathrm{a}$ \\
Dosis I (100 mg/kg BB) & $16,12 \mathrm{bc}$ \\
Dosis II (200 mg/kg BB) & $18,23 \mathrm{bc}$ \\
Dosis III (500 mg/kg BB) & $22,44 \mathrm{~d}$ \\
Dosis IV (1000 mg/kg BB) & $19,43 \mathrm{~cd}$
\end{tabular}

Keterangan: Rerata dengan notasi yang sama menunjukkan tidak berbeda nyata $(\mathrm{p}=0,05)$

Hasil uji lanjut menunjukkan bahwa terdapat perbedaan nyata antara kelompok kontrol negatif dengan kontrol positif, jenis perlakuan dosis I,II, III dan IV.Namun kelompok kontrol negatif tidak berbeda nyata dengan jenis perlakuan dosis III dan nilai antara perlakuan yaitu dosis I dan II tidak berbeda nyata pula. Rerata kadar SOD dari perlakuan dosis III berbeda nyata dengan jenis perlakuan yang lain dengan nilai tertinggi. Kondisi tersebut dapat terjadi akibat pengaruh konsumsi pakan, metabolisme tubuh, dan efektivitas kerja antioksidan dari vitamin E. Hal ini berkaitan dengan pernyataan Zidenberg (1991) yang menyebutkan bahwa aktivitas SOD dipengaruhi oleh status diet dan faktor lingkungan.

Malondialdehid (MDA) dalam Organ Hepar
Berdasarkan hasil pengukuran kadar MDA dari organ hepar tikus yang dilakukan sesudah 4 minggu perlakuan. Rerata kadar MDA dari organ hepar tikus pada kelompok kontrol negatif adalah $0,36 \mathrm{ng} / \mathrm{ml}$, kelompok kontrol positif adalah 0,67 ng/ml, kelompok dosis I 0,55 $\mathrm{ng} / \mathrm{ml}$, kelompok dosis II $0,50 \mathrm{ng} / \mathrm{ml}$, kelompok dosis III $0,39 \mathrm{ng} / \mathrm{ml}$, dan kelompok dosis IV0,47 ng/ml. Kadar MDA organ hepar yang terkecil adalah pada kelompok negatif dan yang terbesar pada kelompok kontrol positif. Kelompok perlakuan pemberian fraksi tidak tersabunkan dosis I, II, III, dan IV secara umum menunjukkan kadar MDA organ hepar yang lebih rendah dibanding kelompok kontrol positif.

Hasil uji statistik ragam (ANOVA) menunjukkan hasil bahwa faktor jenis 
Wahyuni: Efek hepatoprotektor fraksi tidak tersabunkan dari dalms

perlakuan memberikan pengaruh nyata perlu dilakukan uji lanjut Beda Nyata $(\alpha=0,05)$ terhadap kadar MDA organ Terkecil (BNT).

hepar tikus. Berdasarkan hasil tersebut

Tabel 3. Rerata Kadar MDA Organ Hepar pada Berbagai KelompokPerlakuan

\begin{tabular}{lc}
\hline Jenis Perlakuan & Kadar MDA (ng/ml) \\
\hline Kontrol negatif (normal) & $0,36 \mathrm{a}$ \\
Kontrol positif (stres oksidatif) & $0,67 \mathrm{~d}$ \\
Dosis I $100 \mathrm{mg} / \mathrm{kg} \mathrm{BB})$ & $0,55 \mathrm{c}$ \\
Dosis II (200 mg/kg BB) & $0,50 \mathrm{c}$ \\
Dosis III (500 mg/kg BB) & $0,39 \mathrm{ab}$ \\
Dosis IV (1000 mg/kg BB) & $0,47 \mathrm{bc}$
\end{tabular}

Keterangan: Rerata dengan notasi yang sama menunjukkan tidak berbeda nyata $(p=0,05)$

Berdasarkan hasil uji lanjut, dapat diketahui bahwa kadar MDA kelompok kontrol negatif tidak berbeda nyata dengan dosis III. Kadar MDA dosis I, II dan IV pun selisihnya tidak terlalu jauh. Sedangkan kadar MDA pada kelompok perlakuan yang lain yaitu kontrol positif berbeda nyata dengan perlakuan yang lainnya. Kadar MDA organ hepar pada kelompok kontrol positif paling tinggi dengan notasi d dan paling berbeda nyata dengan perlakuan yang lain. Hal ini mengindikasikan tingginya kondisi stres oksidatif akibat induksi minyak jelantah sehingga terjadi akumulasi produk hasil peroksidasi lipid dalam organ yang salah satunya malondialdehid. Tidak ada asupan antioksidan dari luar tubuh untuk membantu kerja enzim antioksidan alami dalam tubuh yang bekerja berat.

Adapun rerata kadar MDA organ hepar untuk kelompok perlakuan yang paling rendah terdapat pada dosis III dibanding pemberian fraksi tidak tersabunkan dosis lain. Hal ini mengindikasikan bahwa pada dosis fraksi tidak tersabunkan sebesar $500 \mathrm{mg} / \mathrm{kg}$ BB dapat menurunkan kadar MDA organ hepar lebih efektif dibanding dosis yang lainnya. 


\section{Morfologi Sel Hepar}

Pengamatan histopatologi sel hepar pada penelitian ini dimaksudkan untuk mengetahui pengaruh pemberian fraksi tidak tersabunkan dari DALMS terhadap kondisi stres oksidatif dengan melihat tingkat kerusakan sel hepar. Menurut Robbins et al. (1999), hepar merupakan organ yang dalam kondisi tertentu dapat mengalami akumulasi substansi hasil metabolisme seperti lemak, karbohidrat, dan protein secara abnormal. Akumulasi ini terjadi secara intraseluler dan bersifat reversible pada kondisi akumulasi yang belum parah.

Secara umum gambaran histopatologi menunjukkan jaringan hati tikus dari semua kelompok perlakuan masih dapat diamati komponenkomponennya dengan jelas. Lobulus hati masih teramati, vena sentral juga terlihat dikelilingi oleh sel-sel hepatosit yang tersusun secara radial dan masih teratur. Hal yang membedakan antara kondisi jaringan satu dengan yang lainnya adalah terjadi perbedaan kerapatan susunan dari sel-sel hati, adanya perbedaan warna secara umum, dan perbedaan ukuran inti sel yang nampak. Selain itu tidak ditemukan adanya ciri-ciri kematian sel. Kematian sel disebut juga nekrosis dimana ciri-cirinya adalah terjadi lisis sel, pengerutan inti sel, penampakan sel yang sangat pucat, bahkan hingga menghilangnya inti sel (Robbins et al., 1999).

\section{Skala Kerusakan Hepar}

Sun et al. (1999), dalam penelitiannya mengkaji induksi etanol sebagai sumber stres oksidatif dan pengaruhnya terhadap morfologi jaringan hati tikus menggunakan skala kualitatif (1-5) untuk menentukan tingkat kerusakan sel hepar. Skala tersebut menunjukkan seberapa besar perubahan struktur histologi dari jaringan hepar dan dengan skala tersebut dilakukan analisis statistik.

Jika dilakukan perbandingan hasil pengamatan histopatologi sel hepar pada penelitian ini dengan menggunakan skala kerusakan hati menurut Sun et al. (1999), maka histologi jaringan hepar tikus dari masing-masing perlakuan dapat diberi skala sesuai dengan tingkat kerusakannya. 
Wahyuni: Efek hepatoprotektor fraksi tidak tersabunkan dari dalms

\section{Tabel 4. Skala Kerusakan Hati pada Berbagai Kelompok Perlakuan}

\begin{tabular}{ll}
\hline Jenis Perlakuan & Skala Kerusakan \\
\hline Kontrol negatif (normal) & 1 \\
Kontrol positif (stres oksidatif) & 2 \\
Dosis I (100 mg/kg BB) & 2 \\
Dosis II (200 mg/kg BB) & 1 \\
Dosis III (500 mg/kg BB) & 1 \\
Dosis IV (1000 mg/kg BB) & 2 \\
\hline
\end{tabular}

Pendeskripsian kelompok perlakuan dengan menggunakan skala kerusakan hati berdasarkan metode Sen et al. (1999), ternyata menunjukkan bahwa tidak terjadi variasi perubahan morfologi jaringan hati dari keenam kelompok perlakuan. Kerusakan terparah hanya pada tahap skala 2, tidak ada tanda nekrosis, maupun steatosis atau akumulasi lemak dalam jaringan. Hal tersebut menandakan bahwa perlakuan stres oksidatif pada penelitian ini hanya memberikan efek cedera sublethal atau cedera reversible pada jaringan hati. Namun ada indikasi bahwa perlakuan pemberian konsentrat vitamin $\mathrm{E}$ pada beberapa kelompok menyebabkan perbaikan kondisi sel atau bersifat melindungi sel dibanding pada kelompok stres oksidatif (kontrol positif). Hal ini didasarkan pada literatur yang menyatakan bahwa cedera reversible tidak menyebabkan kematian sel dan sering disebut cedera sublethal, dimana bila stimulusnya dihentikan maka sel akan kembali pulih seperti sebelumnya (Sudiono, 2003).

\section{Perhitungan Sel Hepar Terdegenerasi}

Oleh karena analisa deskriptif kualitatif pada pengelompokkan skala kerusakan hati masih sangat umum dan kurang dapat memberikan hasil yang terlihat nyata, maka dilakukan pendekatan lain untuk mendukung deskripsi yang ada. Pada gambaran histopatologi sel hepar berbagai kelompok pada penelitian ini terlihat adanya fenomena degenerasi sel, dimana terlihat jelas pada kelompok kontrol positif, dimana ada area jaringan yang tersusun atas sel-sel dengan inti yang tampak membesar dibanding yang lain, berwarna agak pucat dengan tepian inti yang pudar, dan warna dari sitoplasmanya 
lebih muda. Ciri-ciri tersebut mengindikasikan terjadinya degenerasi hidropik.

Pembengkakan sel terjadi jika sel tidak mampu untuk mempertahankan kesimbangan ion pada lingkungan sel. Peristiwa ini merupakan manifestasi awal dari semua bentuk cedera pada sel. Degenerasi hidropik merupakan efek jangka panjang dari pembengkakan sel yang ditunjukkan oleh akumulasi air dalam jumlah besar. Degenerasi memberikan efek penampakan sel yang membesar (Robbins et al., 1999). Eroschenko (2010) juga menambahkan bahwa degenerasi hidropik akan menyebabkan akumulasi cairan pada sitosol, retikulum endoplasma, dan pembengkakan mitokondria. Pada proses ini sitoplasma sel menjadi berwarna muda dan inti sel membengkak.
Setelah mengetahui bahwa terjadi fenomena pembengkakan sel yang berlanjut pada degenerasi hidropik, maka dilakukan penghitungan terhadap sel yang menunjukkan ciri-ciri degenerasi pada setiap preparat jaringan hati dari berbagai perlakuan. Penghitungan sel terdegenerasi dilakukan pada tiap lapangan pandang di bawah pengamatan mikroskop. Pada satu preparat diambil 15 lapangan pandang lalu dihitung rerata jumlah sel terdegenerasi tiap perlakuan.

Hasil uji statistik ragam (ANOVA) menunjukkan hasil bahwa faktor perlakuan pemberian tambahan pakan memberikan pengaruh nyata $(\alpha=0,05)$ terhadap jumlah sel hepar tikus terdegenerasi. Oleh karena itu, dilakukan uji lanjut DMRT.

Tabel 5. Rerata Sel Hepar Terdegenerasi pada Berbagai KelompokPerlakuan

\begin{tabular}{lc}
\hline Jenis Perlakuan & Jumlah sel per lapangan pandang \\
\hline Kontrol negatif (normal) & $0,56 \mathrm{a}$ \\
Kontrol positif (stres oksidatif) & $4,07 \mathrm{~d}$ \\
Dosis I (100 mg/kg BB) & $2,20 \mathrm{c}$ \\
Dosis II (200 mg/kg BB) & $1,36 \mathrm{~b}$ \\
Dosis III (500 mg/kg BB) & $3,93 \mathrm{~d}$ \\
Dosis IV (1000 mg/kg BB) & $2,49 \mathrm{c}$ \\
\hline
\end{tabular}

Keterangan: Rerata dengan notasi yang sama menunjukkan tidak berbeda nyata $(p=0,05)$ 
Hasil dari uji lanjut menunjukkan bahwa jumlah sel hepar terdegenerasi dari perlakuan pemberian fraksi kaya tokotrienol dengan berbagai dosis saling berbeda nyata. Jumlah sel hepar terdegenerasi pada perlakuan dosis I lebih kecil dibanding kontrol positif, sedangkan untuk perlakuan dosis II lebih kecil dibanding dosis I. Namun pada perlakuan dosis III jumlah sel terdegenerasi meningkat dan tidak berbeda nyata dengan kontrol positif yang merupakan perlakuan stres oksidatif saja.

Menurut Sen et al. (2010), tokotrienol mampu melindungi membran sel dengan melindungi komponen PUFA (Polyunsaturated Fatty Acid) pada bagian lipid membran dari serangan radikal bebas. Terlebih lagi tokotrienol mampu disimpan dalam tubuh dan memiliki spesifitas antioksidan pada jaringan (Yamashita et al.,2002). Namun pada dosis yang berlebihan diduga tokotrienol dapat teroksidasi apabila gugus hidroksil pada $\alpha$-tokotrienol dalam keadaan bebas dan sama halnya dengan $\alpha$-tokoferol (Hamm dan Hamilton, 2000).

\section{KESIMPULAN}

Kesimpulan penelitian ini adalah Distilat asam lemak minyak sawit diolah menjadi vitamin E kaya tokotrienol. Pemberian fraksi kaya tokotrienol dari DALMS dapat memberikan perlindungan pada tikus terhadap kondisi stres oksidatif. Jenis perlakuan memberikan pengaruh yang nyata $(\alpha=0,05)$ terhadap kadar MDA dan SOD, aktivitas katalase dari serum darah. Faktor waktu pengambilan sampel berpengaruh yang nyata $(\alpha=0,05)$ terhadap kadar MDA dan SOD serum darah. Vitamin E kaya tokotrienol yang diperoleh dari DALMS mempunyai aktivitas antioksidan yang tinggi dan sebagai antioksidatif secara in vivo yang dapat mencegah strees oksidatif pada tikus dengan menurunkan kadar MDA serum darah dan meningkatkan aktivitas enzim SOD.

\section{UCAPAN TERIMA KASIH}

Ucapan terimakasih disampaikan kepada Ibu Dr. Teti Estiasih, S.TP, MP dan Ibu Dr. Widya Dwi Rukmi Putri, STP, MP dari Universitas Brawijaya Malang 


\section{DAFTAR PUSTAKA}

Ahmadi, K dan T. Estiasih. 2011. Kristalisasi Pelarut Suhu Rendah pada Pembuatan Fraksi Kaya Vitamin E Mengandung Tokotrienol dari Distilat Asam Lemak Minyak Sawit. Jurnal Teknologi dan Industri Pangan, Vol. XXII No.2.

Eroschenko VP. 2010. Atlas Histologi di Fiore dengan Korelasi Fungsional Edisi 11. Jakarta: EGC. Hlm: 324-6, $331,342$.

Gabungan Pengusaha Kelapa Sawit Indonesia, 2011. Industri Minyak Sawit Indonesia Menuju Tahun 2050. Bogor: PAPSI.

Maulana, Hafiz I. 2011. Efek Antioksidan Effervescent Rosella Ungu (Hibiscus sabdariffa L.) terhadap Kondisi Stres Oksidatif pada Tikus Wistar (Rattus norvegicus). Skripsi. FTP-ITP UB. Malang.

Muchlisyiyah, Jhauharotul. 2013. Karakteristik Senyawa Bioaktif Distilat Asam Lemak Minyak Sawit (DALMS) dari Beberapa Industri Pemurnian serta Peningkatan Skala
Saponifikasi pada Separasi Fraksi Tidak Tersabunkan DALMS. Tesis Teknologi Hasil Pertanian. Fakultas Teknologi Pertanian Universitas Brawijaya.

Norhidayah, Baharin B.S, Hamed M, Zaidul I.S. 2012. Squalene Recovery from Fatty Acid Distillate Using Supercritical Fluid Extraction. International Food Research Journal 19(4): 1661-1667 (2012)

Posada, L., R. et al,. 2012. Extraction of tocotrienols from palm fatty acid distillates using molecular distillation. Separation and Purification Technology 57 (2007) 220-229

Puspitasari, R. 2013. Optimasi Destilat Asam Lemak MinyakSawit (DALMS) pada Separasi Fraksi Tidak Tersabunkan Mengandung Senyawa Bioaktif Multi komponen. Skripsi. Universitas Brawijaya Malang.

Riegger, C. 2008. Genistein. http://www.phytochemicals.info.

Diakses tanggal12 September 2013.

Sen,C.K , Cameron R., dan Savita K. 2010. Palm Oil-Derived Natural 
Wahyuni: Efek hepatoprotektor fraksi tidak tersabunkan dari dalms

Vitamin E a-Tocotrienol in Brain

Health and Disease. Journal of the
American College of Nutrition. 29(3): 314S-323S (2010). 